\title{
Respons Orang Hidup Dengan HIV AIDS (OHIDHA) Dalam Upaya Penanggulangan HIV AIDS di Kabupaten Sukoharjo dan Grobogan.
}

\author{
Arrum Firda Ayu Maqfiroch*), Zahroh Shaluhiyah**) \\ *) Alumni Magister Promosi Kesehatan Undip \\ Korespondensi: arum.firda.am@gmail.com \\ **) Magister Promosi Kesehatan Universitas Diponegoro Semarang
}

\begin{abstract}
ABSTRAK
Penanggulangan HIV AIDS membutuhkan keterlibatan dari berbagai pihak. Salah satu pihak yang terlibat adalah OHIDHA. OHIDHA merupakan anggota keluarga yang hidup bersama ODHA dan memberikan dukungan kepada ODHA. Stigma di Kabupaten Sukoharjo dan Grobogan masih tinggi. Penelitian ini bertujuan untuk mengetahui faktor-faktor apakah yang menentukan respons OHIDHA dalam upaya penanggulangan HIV AIDS di Kabupaten Sukoharjo dan Grobogan.

Penelitian ini merupakan penelitian kuantitatif dengan pendekatan cross sectional. Teknik pengambilan data kuantitatif melalui wawancara dengan kuesioner. Penelitian ini didukung dengan penelitian kualitatif dengan teknik pengambilan data FGD. Jumlah responden adalah 92 OHIDHA, proporsi 50\% dan selang kepercayaan 95\%. Analisis data menggunakan analisis univariat dengan distribusi frekuensi, bivariat menggunakan Chi-Square dan multivariat menggunakan regresi logistik.

Hasil penelitian menunjukkan bahwa variabel yang berhubungan dengan respons OHIDHA adalah hubungan dengan ODHA ( $p$-value=0,001), lama hidup dengan ODHA ( $p$-value=0,030), lama mengetahui status ODHA ( $p$-value $=0,001)$ dan sikap $(p$-value $=0,005)$. Hasil analisis multivariat menunjukkan bahwa sikap ( $p$-value $=0,006$ ) merupakan variabel yang mempunyai pengaruh paling signifikan dibanding variabel lainnya.
\end{abstract}

Kata Kunci : OHIDHA, respons, Grobogan, Sukoharjo

\section{ABSTRACT}

Respons of People Living With HIV AIDS to Control HIV and AIDS in Sukoharjo and Grobogan District; Controlling HIV and AIDS requird the involvement of various sector. One of the sector involved is People Living With HIV AIDS (PLWHA). PLWHA is a family member who lives with people living with HIV and provide support to people living with HIV. Stigma in Sukoharjo and Grobogan still high. This study aims to determine the factors that determine whether the PLWHA response in control to HIV and AIDS in Sukoharjo Grobogan. This research was a quantitative study with cross sectional approach. Quantitative data collection techniques through interviews with questionnaires. This research was supported by qualitative research with FGD. The number of respondents was 92 PLWHA, the proportion of 50\% and $95 \%$ confidence interval. Analysis of the data using univariate analysis with frequency distribution, bivariate using Chi-Square and multivariate using logistic regression. The results showed that the variables related to the PLWHA response is a relationship with people living with $H I V(p=0,001)$, long life with people living with HIV $(p=0.030)$, longer know the status of PLWHA ( 0.001$)$ and attitude $(p=0.005)$. Multivariate analysis showed that the attitude $(p$ value $=0,006)$ was a variable that has the most significant effect compared to other variables.

Keywords : AIDS, response, Grobogan, Sukoharjo 


\section{PENDAHULUAN}

Masalah yang dihadapi oleh ODHA sangat kompleks, untuk mengatasi masalah itu maka diperlukan layanan komprehensif yang melibatkan anggota keluarga yang hidup bersama dengan ODHA dan memberikan perhatian kepada mereka (OHIDHA). Peran OHIDHA sangat berpengaruh terhadap kehidupan ODHA (Nasronudin, 2010).

Penelitian yang pernah dilakukan di Asia (India, Indonesia, Filipina, Thailand) bahwa $80 \%$ dari responden melaporkan pengalaman stigma dan diskriminasi. Termasuk diskriminasi di keluarga sebanyak 18\% (UNAIDS, 2011). Dimana keluarga seharusnya menjadi titik tumpu dalam upaya $C S T-P P R R$. Apabila respons keluarga (OHIDHA) negatif, dapat menyebabkan gangguan perilaku pada ODHA, termasuk menghindari kontak fisik dan sosial. Kemarahan yang dirasakan oleh ODHA akan berakibat terjadinya upaya menularkan kembali virus HIV pada orang lain dengan sengaja, apabila ini terjadi maka akan bertambah besar masalah HIV AIDS di masyarakat (Narodin, 2007). Selain itu, respons yang negatif dari keluarga dapat mengurangi keinginan individu untuk melakukan tes HIV, pengungkapan status, praktek seks aman, dan mengakses pelayanan kesehatan termasuk ARV. Begitu juga yang terjadi di
Kabupaten Sukoharjo dan Kabupaten Grobogan. Banyak ODHA di Sukoharjo yang mengaku kesulitan untuk membuka statusnya dengan keluarga. Akibatnya ODHA kesulitan untuk mengakses pengobatan, mereka membatasi diri jika ingin berobat dan keengganan untuk melakukan tes HIV.

Selama lima tahun terakhir sejak tahun 2009 sampai dengan September tahun 2013 di Kabupaten Sukoharjo ditemukan kasus AIDS sebanyak 88 dan kasus HIV sebanyak 45 kasus.

Di Kabupaten Grobogan, ODHA dikucilkan oleh keluarga setelah dia mengungkapkan status HIV nya. Keluarga tidak pernah memberikan dukungan, baik dukungan pengobatan maupun perawatan kepada ODHA. Selain itu, beberapa ODHA di Kabupaten Grobogan lebih memilih untuk mengambil ARV di luar wilayah Grobogan dengan alasan agar tidak bertemu dan diketahui oleh pihak keluarga dan petugas kesehatan yang bekerja di rumah sakit terdekat.

Dengan latar belakang permasalahan di atas, maka perlunya untuk mengetahui faktor determinan respons OHIDHA terhadap ODHA dalam upaya penanggulangan HIV AIDS di Kabupaten Sukoharjo dan Kabupaten Grobogan 


\section{METODE PENELITIAN}

Penelitian ini merupakan penelitian kuantitatif dengan pendekatan cross sectional. Selain itu, penelitian ini didukung dengan pendekatan kualitatif yaitu dengan diskusi kelompok terarah. Lokasi penelitian adalah Kabupaten Sukoharjo dan Kabupaten Grobogan. Populasi penelitian adalah semua OHIDHA di Kabupaten Sukoharjo yang ODHA nya tercatat sebagai anggota KDS atau telah dijangkau oleh LSM setempat. Sampel penelitian adalah sebanyak 92 orang. pengambilan sampel dengan menggunakan teknik purposive sampling. Variabel yang diteliti dalam penelitian ini adalah karakteristik OHIDHA yang meliputi umur, pendidikan, pekerjaan, hubungan dengan ODHA, agama, lama hidup dengan ODHA, lama mengetahui status ODHA dan sumber mendengar anggota keluarga berstatus ODHA, pengetahuan OHIDHA, sikap OHIDHA, kepercayaan terhadap mitos HIV AIDS, keikutsertaan dalam sosialisasi HIV AIDS, sumber informasi HIV AIDS, dukungan keluarga, dukungan teman serta dukungan tokoh dan respons OHIDHA. Penelitian dilakukan pada tahun 2014 dengan pengumpulan data menggunakan wawancara kuesioner.

\section{HASIL DAN PEMBAHASAN}

\section{Respons OHIDHA}

Hasil analisis deskriptif menunjukkan bahwa $57,6 \%$ responden mempunyai respons positif pada saat ini dan 53,3\% pada saat awal, sedangkan sisanya sebesar $42,4 \%$ responden mempunyai respons negatif pada saat ini dan $46,7 \%$ pada saat awal. Secara lebih mendalam, perubahan respons negatif terjadi pada tindakan OHIDHA dalam mencemooh ODHA, dari awal sebesar $39,1 \%$ menjadi $1,1 \%$. Artinya, dampak dari respons OHIDHA yang negatif terhadap ODHA yaitu adanya tindakan mencemooh ODHA yang dilakukan oleh OHIDHA. Selain itu, perubahan respons negatif juga terjadi pemberian bantuan berobat bagi ODHA, dari awal OHIDHA yang tidak memberikan bantuan berobat bagi ODHA sebesar $85,9 \%$ menjadi $46,7 \%$. Artinya, dampak dari respons OHIDHA yang negatif terhadap ODHA yaitu adanya tindakan pemberian bantuan pengobatan bagi ODHA. Hal ini sesuai dengan penelitian Narodin dan teori stigma bahwa stigma mempunyai implikasi yang mendalam salah satunya terhadap pengobatan HIV. Respons negatif juga berhubungan dengan pengungkapan status ODHA yaitu pada OHIDHA yang memberikan respons positif kepada ODHA maka ODHA lebih terbuka kepada keluarga. 
Hasil respons OHIDHA saat ini sesuai dengan penelitian yang yang pernah dilakukan di Asia (India, Indonesia, Filipina, Thailand) bahwa $80 \%$ dari responden melaporkan pengalaman stigma dan diskriminasi. Termasuk diskriminasi di keluarga sebanyak 18\% (UNAIDS,2011). Penelitian ini berbeda dengan hasil visitasi yang dilakukan oleh Komisi Penanggulangan AIDS Provinsi Jawa Tengah bahwa stigma di Kabupaten Grobogan sangat tinggi (KPAP,2013). Hal ini bisa saja terjadi karena respons yang ditanyakan adalah respons sekarang. Sementara tidak menutup kemungkinan keluarga menjawab tidak jujur karena untuk menutupi aib keluarganya agar terlihat baik oleh orang lain. Selain itu, menurut hasil FGD bahwa mereka beralasan memberi respons yang positif karena merasa kasihan dengan anggota keluarga dan seperti apapun keluarga pasti akan tetap dirangkul, terlebih lagi bagi yang menganggap keluarga mereka sebagai korban.

OHIDHA yang mempunyai respons negatif yaitu tidak memberikan bantuan materi untuk berobat sebesar $46,7 \%$. Hal ini sesuai dengan penelitian yang dilakukan oleh Nugrahawati tentang bentuk dukungan keluarga kepada ODHA yaitu ODHA yang mendapatkan bantuan materi hanya $15 \%$. Menurut Nugrahawati, sebanyak $50 \%$ ODHA membutuhkan dukungan berupa perhatian, empati, berbagi perasaan dan merasa dihargai. Dalam penelitian ini, dukungan OHIDHA yang tidak menghiburnya sebesar $32,6 \%$. Kemudian, terkait dengan partisipasi perawatan ODHA, bahwa menurut Nugrahawati bentuk dukungan akses layanan kesehatan hanya $15 \%$ dimana hal ini sesuai dengan penelitian ini bahwa keluarga yang tidak ikut merawatnya sebesar 29,3\%. Maka, penelitian ini sesuai dengan penelitian yang dilakukan oleh Nugrahawati (Nugrahawati, 2011).

Berdasarkan hasil penelitian ini, dapat diketahui bahwa beberapa faktor yang memiliki hubungan signifikan secara statistik terhadap respons OHIDHA yaitu hubungan dengan ODHA, lama hidup dengan ODHA, lama mengetahui status ODHA dan sikap. Hubungan yang terjadi diantara faktor-faktor tersebut dengan respons OHIDHA menunjukkan adanya beberapa kecenderungan yaitu responden yang mempunyai hubungan sebagai keluarga bukan inti memiliki kecenderungan untuk memberikan respons positif dibanding dengan responden yang mempunyai hubungan keluarga sebagai keluarga inti. Responden yang sudah lama hidup dengan ODHA memiliki kecenderungan untuk memberikan respons positif dibanding dengan responden yang masih baru hidup dengan ODHA. Responden yang masih baru mengetahui status ODHA memiliki kecenderungan 
untuk memberikan respons positif dipengaruhi oleh sikap. Dalam penelitian dibanding dengan responden yang sudah ini adalah sikap OHIDHA. Selain itu, di lama mengetahui status ODHA. Responden dalam penelitian ini juga mengungkapkan yang mempunyai sikap positif memiliki kecenderungan untuk memberikan respons positif dibandingkan dengan responden yang memiliki sikap negatif.

Berdasarkan nilai odds ratio yang diperoleh dari hasil multivariat, menunjukkan bahwa variabel sikap memiliki pengaruh terhadap respons OHIDHA di Kabupaten Sukoharjo dan Kabupaten Grobogan. OHIDHA yang mempunyai sikap yang positif memiliki kecenderungan 4,118 lebih besar untuk memberikan respons yang positif dibanding dengan OHIDHA yang mempunyai sikap negatif. Selain itu, variabel lain yang memiliki pengaruh terhadap respons OHIDHA adalah variabel lama mengetahui status HIV ODHA yang memiliki kecenderungan 0,246 lebih besar untuk memberikan respons negatif dibanding dengan OHIDHA yang baru mengetahui status ODHA. Selain itu, variabel hubungan kekeluargaan dengan ODHA juga mempunyai pengaruh terhadap respons OHIDHA yaitu bahwa OHIDHA yang mempunyai hubungan kekeluargaan sebagai keluarga inti memiliki kecenderungan 0,149 lebih besar untuk memberikan respon negatif. Hal ini sesuai dengan teori Green terdapat (predisposing factor) bahwa dalam berperilaku seseorang mengetahui status OHIDHA dan hubungan dengan ODHA) merupakan faktor yang mempengaruhi respons OHIDHA.

Penelitian ini mengungkapkan bahwa respons OHIDHA ditentukan oleh karakteristik di dalamnya termasuk hubungan dengan ODHA, lama hidup dengan ODHA, lama mengetahui status ODHA dan sikap yang masuk di dalam faktor predisposisi menurut teori Green. Selain itu, sama halnya dengan penelitian yang dilakukan di Papua tentang stigma dan HIV AIDS di Wilayah Pegunungan Papua mengungkapkan bahwa pengungkapan status oleh ODHA akan menyebabkan diperolehnya dukungan dari keluarga (UNCEN, 2010).

Sedangkan faktor yang paling mempengaruhi respons OHIDHA adalah sikap, lama mengetahui status HIV dan hubungan dengan ODHA. Faktor ini merupakan stimulus langsung bagi OHIDHA. Faktor sikap yang positif menyebabkan adanya stimulus untuk memberikan respons positif.

Menurut Sobur, bahwa respons yang berarti balasan atau tanggapan suatu rangsang, dilatarbelakangi oleh sikap, persepsi, dan partisipasi. Respons pada prosesnya didahului sikap seseorang karena 
sikap merupakan kecenderungan atau kesediaan seseorang untuk bertingkah laku jika menghadapi suatu rangsangan tertentu. Pada penelitian ini, sikap responden mayoritas baik, sehingga sesuai dengan respons responden yang mayoritas adalah positif. $^{50}$ Sedangkan menurut Azwar, respons terdiri dari 3 komponen yaitu komponen kognisi (pengetahuan), komponen afeksi (sikap) dan komponen psikomotorik (tindakan). Pengetahuan berhubungan dengan bagaimana seseorang memperoleh pemahaman tentang dirinya dan lingkungannya serta bagaimana dengan kesadaran itu mereka bereaksi terhadap lingkungannya (Azwar, 2007).

Pengetahuan OHIDHA tentang HIV AIDS

Berdasarkan hasil analisis statistik univariat menunjukkan bahwa pengetahuan responden terhadap respons OHIDHA setengahnya dalam kategori baik yaitu sebesar 63\%, sedangkan dengan kategori kurang sebanyak 37\%. Secara lebih mendalam lagi, dapat diketahui bahwa responden yang mempunyai pengetahuan kurang mengenai HIV AIDS antara lain sebanyak 90,2\% OHIDHA menyatakan bahwa HIV dapat diidentifikasi melalui fisik dan sebanyak $89,1 \%$ menyatakan bahwa HIV dapat diidentifikasi melalui perilaku. Sebanyak 72,8\% OHIDHA menyatakan bahwa tes VCT bisa dilakukan di bidan / perawat. Sebanyak 60,9\%
OHIDHA menyatakan bahwa HIV tidak menular melalui tato. Sebanyak 60,9\% OHIDHA menyatakan bahwa ODHA tidak boleh hamil. Sebanyak 51,4\% OHIDHA tidak mengetahui tentang VCT. Sebanyak 30,4\% OHIDHA menyatakan bahwa HIV tidak dapat ditularkan dari ibu ke bayi pada saat persalinan. Sebanyak 26,1\% OHIDHA menyatakan bahwa virus HIV dapat ditularkan melalui gigitan nyamuk. Sebanyak 21,7\% OHIDHA menyatakan bahwa HIV tidak menular melalui penggunaan jarum suntik yang tidak steril secara bergantian. Dari beberapa hal terkait dengan pengetahuan yang kurang, sebanyak $40,2 \%$ OHIDHA tidak pernah membicarakan tentang cara pencegahan HIV.

Hasil analisis bivariat menunjukkan bahwa uji statistik dengan Chi-Square diperoleh $p$ value 0,177 yang lebih besar dari 0,05 yang secara statistik tidak signifikan sehingga dapat diketahui bahwa tidak terdapat hubungan antara pengetahuan HIV AIDS dengan respons OHIDHA.

Hasil ini sesuai dengan penelitian sebelumnya tentang Analisis Beberapa Faktor yang Mempengaruhi Perilaku Masyarakat dalam Menghadapi Penderita HIV dan AIDS bahwa tingkat pengetahuan responden baik tetapi tidak ada hubungan yang bermakna antara tingkat pengetahuan dalam menghadapi penderita HIV AIDS (Kristi, 2008). 
Berdasarkan hasil tabulasi silang memberikan respons yang positif. menurut pengetahuan HIV AIDS diketahui Mayoritas responden mempunyai bahwa dari 34 OHIDHA yang mempunyai pengetahuan tentang HIV AIDS yang baik. pengetahuan HIV kurang yaitu skor Dengan demikian, membentuk respons pengetahuan kurang dari 13 yang positif OHIDHA. Namun demikian, memberikan respon negatif sebesar 52,9\% pengetahuan OHIDHA tentang HIV AIDS lebih banyak proporsinya dibandingkan belum komprehensif. $\mathrm{Hal}$ ini bisa dengan yang mempunyai pengetahuan baik dibuktikan bahwa masih ada pemahaman yaitu skor pengetahuan lebih dari sama yang salah dari OHIDHA tentang dengan skor $13(36,2 \%)$. Hal ini pengetahuan HIV AIDS seperti cara menunjukkan bahwa responden yang mempunyai pengetahuan tinggi cenderung untuk memberikan respons positif daripada responden dengan pengetahuan kurang.

Menurut teori Green, terdapat 3 kategori utama dalam mempengaruhi perilaku seseorang. Salah satunya adalah faktor predisposisi yang di dalamnya terdapat pengetahuan. Pengetahuan merupakan hasil tahu dan ini terjadi setelah seseorang melakukan penginderaan terhadap suatu objek tertentu. Penginderaan terjadi melalui panca indera penglihatan, penginderaan penciuman, rasa dan raba. Sebagian besar manusia memperoleh melalui mata dan telinga, pengetahuan atau kognitif merupakan domain yang sangat penting dalam membentuk seseorang (Notoatmodjo, 2010).

Pengetahuan HIV AIDS OHIDHA yang sebagian besar sudah dalam kategori baik menyebabkan respons positif penularan HIV AIDS, cara mengidentifikasi HIV AIDS dan VCT.

Berdasarkan hasil Riskesdas bahwa pengetahuan komprehensif tentang HIV/AIDS ditentukan lima hal yaitu bahwa HIV dapat dicegah dengan berhubungan seksual dengan suami/istri saja, HIV dapat dicegah dengan menggunakan kondom saat berhubungan seksual dengan pasangan berisiko, HIV AIDS dapat dicegah dengan tidak menggunakan jarum suntik bersama, HIV AIDS tidak dapat menular karena makan sepiring bersama dengan penderita AIDS, dan HIV AIDS tidak bisa ditularkan melalui gigitan nyamuk. Secara nasional $11,4 \%$ penduduk mempunyai pengetahuan komprehensif tentang HIV AIDS. Hal ini menunjukkan kesesuaian hasil penelitian dengan hasil Riskesdas bahwa pengetahuan komprehensif tentang HIV AIDS bagi masyarakat masih kurang (KEMENKES, 2010).

OHIDHA. Pengetahuan HIV AIDS Berdasarkan hasil FGD dengan ODHA, mempengaruhi kognitif OHIDHA dalam OHIDHA mendapatkan informasi HIV 
AIDS dari ODHA dan provider ketika mengantarkan ODHA mengakses layanan kesehatan. Ini merupakan salah satu bentuk edukasi dalam rangka meningkatkan pengetahuan OHIDHA khususnya mengenai HIV AIDS. Karena kognitif merupakan domain yang sangat penting untuk terbentuknya tindakan seseorang (overt behavior), maka sangat pentingnya upaya yang harus dilakukan untuk peningkatan pengetahuan OHIDHA secara komprehensif dan berkesinambungan mengingat ilmu tentang HIV AIDS sangat dinamis.

Berdasarkan hasil FGD, sosialisasi tentang HIV AIDS hanya diberikan ketika ada kasus. Sosialisasi dilakukan guna meningkatkan pengetahuan keluarga khususnya dan untuk masyarakat pada umumnya. Sosialisasi tentang HIV AIDS selama ini tidak dilakukan langsung kepada masyarakat, tetapi hanya dilakukan kepada pejabat seperti camat dan lurah. Sehingga masih banyak masyarakat yang kurang mempunyai pengetahuan tentang HIV AIDS yang komprehensif. Hal ini sesuai dengan hasil Riset Kesehatan Dasar bahwa pengetahuan masyarakat tentang HIV AIDS secara komprehensif masih rendah.

\section{Sikap / Stigma terhadap ODHA}

Berdasarkan hasil penelitian menunjukkan bahwa setengah dari responden mempunyai sikap yang positif terhadap HIV AIDS yaitu sebesar 56,5\%, sedangkan responden yang mempunyai sikap negatif yaitu sebesar $43,5 \%$. Secara lebih mendalam lagi, dapat diketahui bahwa responden yang mempunyai sikap negatif yaitu sebanyak $64,1 \%$ OHIDHA takut untuk tertular ODHA hanya dengan berhubungan sosial biasa. Sebanyak 53,3\% OHIDHA meminta ODHA untuk berhenti bekerja ketika terinfeksi HIV meskipun ODHA tidak tampak sakit. Sebanyak 43,5\% OHIDHA memilih untuk mengerjakan segala sesuatunya sendiri daripada bersama ODHA. Sebanyak 42,4\% OHIDHA menyatakan bahwa ODHA harus malu dengan diri mereka sendiri. Sebanyak $37 \%$ OHIDHA merasa nyaman saat minum menggunakan peralatan (botol/gelas) yang sama dengan ODHA. Sebanyak 35,9\% OHIDHA merasa khawatir saat memakai kacamata bersama ODHA. Sebanyak 35,9\% OHIDHA menyatakan bahwa ODHA harus diperlakukan berbeda.Sebanyak 26,1\% OHIDHA tidak merasa nyaman jika menggunakan kamar mandi bersama ODHA

Berdasarkan hasil analisis uji ChiSquare diperoleh $p$ value 0,005 yang lebih kecil dari 0,05 yang berarti secara statistik adalah signifikan sehingga dapat diketahui bahwa sikap responden berhubungan terhadap respons OHIDHA.

Hasil tabulasi silang juga menunjukkan bahwa sikap responden diketahui bahwa dari 40 OHIDHA yang mempunyai sikap 
negatif yaitu skor sikap kurang dari 9 yang memberikan respon negatif sebesar 60,0\% lebih banyak proporsinya dibandingkan dengan yang mempunyai sikap positif yaitu skor sikap lebih dari sama dengan 9 $(28,8 \%)$.

Hal ini sesuai dengan penelitian Natalia Kristi yang berjudul Analisis Beberapa Faktor yang Mempengaruhi Perilaku Masyarakat Menghadapi Penderita HIV dan AIDS di desa Kramat Kecamatan Kranggan Kabupaten Temanggung menunjukkan bahwa variabel sikap masyarakat merupakan faktor yang berhubungan dengan perilaku masyarakat dalam menghadapi penderita HIV AIDS. Pada penelitian ini variabel sikap juga mempunyai hubungan yang signifikan dengan respons OHIDHA (Kristi, 2008).

Sikap merupakan reaksi atau respon seseorang yang masih tertutup terhadap suatu objek. Manifestasi sikap tidak dapat langsung dilihat, tetapi hanya dapat ditafsirkan terlebih dahulu dari perilaku yang tertutup. Sikap secara nyata menunjukkan kondisi adanya kesesuaian reaksi terhadap stimulus tertentu. Sikap merupakan tindakan atau aktivitas, merupakan predisposisi tindakan atau perilaku. Sikap masih merupakan reaksi tertutup, bukan merupakan reaksi tingkah laku yang terbuka (Notoatmodjo, 2003). Menurut Allpont sikap mempunyai 3 komponen pokok yaitu kepercayaan (keyakinan), ide dan konsep terhadap suatu objek, kehidupan emosional atau evaluasi emosional terhadap suatu objek dan kecenderungan untuk bertindak (trend to behave).

Penelitian ini mengungkapkan bahwa berdasarkan hasil FGD kepada ODHA didapatkan hasil bahwa responden yang memberikan respons positif karena sudah diberikan informasi oleh keluarga dan provider, alasan keluarga, dan sebagian besar adalah korban dari pasangannya sehingga merasa kasihan. Selain itu, hal ini juga disebabkan oleh pengetahuan responden yang mayoritas baik.

\section{Kepercayaan terhadap Mitos HIV AIDS}

Berdasarkan hasil penelitian menunjukkan bahwa setengah dari responden mempunyai kepercayaan terhadap mitos HIV AIDS yang positif yaitu sebesar $67,4 \%$ sedangkan responden yang mempunyai kepercayaan negatif terhadap mitos HIV AIDS sebesar 32,6\%. Sebanyak $89,1 \%$ OHIDHA setuju bahwa HIV dan AIDS adalah penyakit karena penyimpangan seksual. Sebanyak $88 \%$ OHIDHA menyatakan bahwa pengidap HIV mengetahui jika dirinya sakit. Sebanyak 64,1\% OHIDHA menyatakan bahwa mengalami nafsu makan menurun disertai berat badan turun drastis sudah pasti tanda-tanda terinfeksi HIV. Sebanyak $60,9 \%$ OHIDHA menyatakan bahwa melawan AIDS itu mustahil. Sebanyak 
$56,5 \%$ OHIDHA menyatakan bahwa berhubungan seks sekali saja tanpa kondom tidak ada resiko tertular HIV. Sebanyak 55, 4\% OHIDHA menyatakan bahwa HIV dan AIDS sama. Sebanyak 48,9\% OHIDHA menyatakan bahwa bayi yang dilahirkan oleh seorang perempuan yang HIV positif pasti akan tertular HIV dari ibunya. Sebanyak $44,6 \%$ OHIDHA menyatakan bahwa sama-sama HIV tidak perlu pengaman saat seks. Sebanyak 22,8\% OHIDHA menyatakan bahwa tidak perlu waspada HIV. Sebanyak 21,7\% OHIDHA menyatakan bahwa HIV hanya menular pada pekerja seks.

Berdasarkan hasil analisis uji ChiSquare diperoleh $p$ value 0,210 yang lebih besar dari 0,05 yang berarti secara statistik adalah tidak signifikan sehingga dapat diketahui bahwa kepercayaan terhadap mitos HIV AIDS responden tidak berhubungan terhadap respons OHIDHA.

Hasil tabulasi silang menurut kepercayaan tentang mitos HIV AIDS responden diketahui bahwa dari 30 OHIDHA yang mempunyai kepercayaan negatif yaitu skor kepercayaan kurang dari 8 yang memberikan respon negatif sebesar $53,3 \%$ lebih banyak proporsinya dibandingkan dengan yang mempunyai kepercayaan positif yaitu skor kepercayaan lebih dari sama dengan $8(37,1 \%)$

Menurut teori Green, terdapat 3 kategori utama dalam mempengaruhi 101 perilaku seseorang. Salah satunya adalah faktor predisposisi yang di dalamnya terdapat kepercayaan. Kepercayaan merupakan keyakinan, ide, konsep terhadap objek. Dalam hal ini keyakinan terhadap issue yang berkembang di masyarakat tanpa ditelusuri benar atau salahnya. Mitos bukan suatu hal yang baru bagi masyarakat, sejak jaman dahulu mitos berkembang pesat dan banyak mitos dalam masyarakat. Mitos sangat dipercaya oleh masyarakat, walaupun secara ilmiah terbukti ketidakbenarannya. Mitos seputar isu yang terkait HIV dan AIDS juga sangat banyak berkembang di masyarakat. Berkembangnya mitos ini menjadi salah satu penghambat jalannya program penanggulangan HIV dan AIDS di dunia. Mengantisipasi mitos yang saat ini berkembang dan dipercaya oleh masyarakat merupakan salah satu tindakan yang harus segera dilakukan untuk mendukung program penanggulangan HIV dan AIDS (Nugrahawati,2011). Dari hasil penelitian ini, meskipun kepercayaan terhadap mitos HIV AIDS responden mayoritas baik, tetapi tetap dibutuhkan pemahaman yang komprehensif tentang HIV AIDS khususnya tentang mitos HIV AIDS karena masih ada $32,6 \%$ responden yang masih percaya dengan mitos HIV AIDS. Sebanyak $89,1 \%$ OHIDHA setuju bahwa HIV dan AIDS adalah penyakit karena penyimpangan seksual padahal HIV dan 
AIDS merupakan penyakit yang bisa menular melalui darah, cairan kelamin dan ASI. Sebanyak 88\% OHIDHA menyatakan bahwa pengidap HIV mengetahui jika dirinya sakit. Padahal untuk mengetahui status HIV AIDS hanya bisa dilakukan menggunakan tes darah. Kepercayaankepercayaan ini menunjukkan bahwa kepercayaan negatif merupakan penghambat jalannya program penanggulangan HIV dan AIDS di dunia

\section{Keikutsertaan Sosialisasi HIV AIDS}

Berdasarkan hasil penelitian menunjukkan bahwa sebagian besar responden tidak pernah mengikuti sosialisasi HIV AIDS yaitu sebesar 64,1\% dan responden yang pernah mengikuti sosialisasi HIV AIDS sebesar 33\%. Secara lebih mendalam, bagi responden yang pernah mengikuti kegiatan sosialisasi Bagi responden yang mengikuti sosialisasi sebanyak $42,4 \%$ OHIDHA tidak mendapatkan informasi tentang sejarah HIV AIDS. Sebanyak 27,3\% OHIDHA tidak mendapatkan informasi tentang stigma. Sebanyak 24,2\% OHIDHA tidak mendapatkan informasi perjalanan infeksi HIV AIDS. Sebanyak 24,2\% tidak mendapatkan informasi tentang diskriminasi.

Berdasarkan hasil analisis uji ChiSquare diperoleh $p$ value 0,512 yang lebih besar dari 0,05 yang berarti secara statistik adalah tidak signifikan sehingga dapat diketahui bahwa keikutsertaan sosialisasi tentang HIV AIDS responden tidak berhubungan terhadap respons OHIDHA.

Berdasarkan hasil tabulasi silang menunjukkan bahwa dari 59 OHIDHA yang tidak pernah mengikuti sosialisasi HIV AIDS yang memberikan respon negatif sebesar $45,8 \%$ lebih banyak proporsinya dibandingkan dengan yang pernah mengikuti sosialisasi HIV AIDS $(36,4 \%)$. Dengan demikian banyak responden dengan keikutsertaan sosialisasi HIV AIDS partisipatif maka semakin tinggi responden yang mempunyai respons positif. Begitu juga sebaliknya, pada responden dengan keikutsertaan sosialisasi HIV AIDS kurang partisipatif maka semakin tinggi responden yang mempunyai respon negatif.

Menurut Green, perilaku ditentukan oleh 3 faktor yang salah satunya adalah faktor pemungkin (enabling factor). Hal ini sejalan dengan teori WHO yang mengatakan bahwa alasan orang berperilaku antara lain didasari oleh alasan adanya sumber daya (resource) yang tersedia. Kedua teori tersebut menjelaskan bahwa seseorang akan berperilaku apabila tersedia sarana, termasuk ada dan tidaknya media informasi yang ada di sekitar lingkungan OHIDHA (Green, 2000).

Hal ini sesuai dengan hasil uji tabulasi silang yang menunjukkan bahwa responden yang mempunyai keikutsertaan partisipatif cenderung mempunyai respons yang positif 
daripada responden yang mempunyai keikutsertaan kurang partisipatif.

Berdasarkan hasil FGD dengan ODHA, keikutsertaan OHIDHA tergantung dari ada dan tidaknya sosialisasi dari tokoh agama dan tokoh masyarakat.

Berdasarkan hasil FGD, sosialisasi selama ini dilakukan hanya ketika ada kasus fatal. Terkait sosialisasi informasi tentang HIV AIDS harus lebih ditingkatkan lagi dengan memberdayakan tokoh agama dan tokoh masyarakat. Selama ini, OHIDHA memperoleh informasi tentang HIV AIDS berasal dari ODHA dan provider. Hal ini dilakukan untuk mengurangi stigma di masyarakat.

\section{Sumber Informasi HIV AIDS}

Berdasarkan hasil penelitian menunjukkan bahwa sebagian besar responden mempunyai sumber informasi yang banyak yaitu sebanyak 98,9\% OHIDHA tidak mendapatkan informasi dari VCD. Sebanyak 96,7\% OHIDHA tidak mendapatkan informasi dari email. Sebanyak 93,5\% OHIDHA tidak mendapatkan informasi dari tabloid. Sebanyak 91,3\% OHIDHA tidak mendapatkan informasi dari sosial media (facebook dan twitter). Sebanyak 91,3\% OHIDHA tidak mendapatkan informasi dari majalah. Sebanyak 83,7\% OHIDHA tidak mendapatkan informasi dari media koran. Sebanyak $77,2 \%$ OHIDHA tidak mendapat informasi dari tokoh masyarakat. Sebanyak
$76,1 \%$ tidak mendapat informasi dari tokoh agama. Sebanyak 71,7\% OHIDHA tidak mendapat informasi dari radio. Sebanyak 68,5\% OHIDHA tidak pernah memperoleh informasi dari pihak teman. Sebanyak $66,3 \%$ OHIDHA tidak mendapat informasi dari internet. Sebanyak 33,7\% OHIDHA tidak pernah memperoleh informasi dari pihak keluarga.

Berdasarkan hasil analisis uji ChiSquare diperoleh $p$ value 0,399 yang lebih besar dari 0,05 yang berarti secara statistik adalah tidak signifikan sehingga dapat diketahui bahwa sumber informasi responden tidak berhubungan terhadap respons OHIDHA.

Hasil tabulasi silang menunjukkan bahwa dari 78 OHIDHA yang mempunyai sumber informasi banyak yaitu skor sumber informasi lebih dari sama dengan 1 yang memberikan respon negatif sebesar $44,9 \%$ lebih banyak proporsinya dibandingkan dengan yang mempunyai sumber informasi sedikit yaitu skor sumber informasi kurang dari 1 (28,6\%). Semakin banyak responden dengan sumber informasi banyak maka semakin tinggi responden yang mempunyai respons negatif.

Menurut Green, perilaku ditentukan oleh 3 faktor yang salah satunya adalah faktor pemungkin (enabling factor). Hal ini sejalan dengan teori WHO yang mengatakan bahwa mengapa orang berperilaku antara lain didasari oleh alasan 
adanya sumber daya (resource) yang tersedia. Kedua teori tersebut menjelaskan bahwa seseorang akan berperilaku apabila tersedia sarana, termasuk ada dan tidaknya sumber informasi yang ada di sekitar lingkungan OHIDHA (Green, 2000). Sumber informasi yang OHIDHA dapatkan mayoritas adalah dari keluarga. Artinya, bahwa informasi yang diberikan oleh keluarga lebih disukai dan lebih mudah diterima oleh OHIDHA.

Menurut hasil FGD, mereka menerima ODHA dengan alasan kemanusiaan, karena ODHA merupakan bagian keluarga mereka. Sehingga, meskipun sumber informasi OHIDHA kurang, mereka tetap memberikan respons yang positif kepada ODHA. Selain itu, informasi yang responden dapatkan bukan merupakan informasi tentang HIV AIDS yang komprehensif.

\section{Dukungan Keluarga}

Berdasarkan hasil penelitian menunjukkan bahwa sebagian besar responden mempunyai dukungan keluarga yang mendukung yaitu sebesar 70,7\% sedangkan responden yang mempunyai dukungan keluarga kurang mendukung sebesar 29,3\%. Secara lebih mendalam, responden yang mendapatkan dukungan keluarga kurang mendukung yaitu sebanyak $66,3 \%$ keluarga tidak memberikan layanan informasi dan petunjuk perawatan kesehatan kepada ODHA. Sebanyak 66,3\% keluarga tidak memberikan bantuan obat untuk ODHA. Sebanyak 55,4\% keluarga tidak menghabiskan waktu dan melakukan kegiatan bersama ODHA. Sebanyak 30,4\% OHIDHA tidak melibatkan suatu kerja sama ODHA, sebanyak 31,5\% keluarga tidak memberikan bantuan materi untuk berobat. Sebanyak 29,3\% keluarga tidak menemani dan mengantar ODHA untuk berobat. Sebanyak $21,7 \%$ keluarga tidak memberikan saran dan nasihat untuk ODHA. Sebanyak 20,7\% keluarga tidak memberikan kesempatan kepada ODHA untuk bertanya dan bercerita tentang masalahnya.

Berdasarkan hasil analisis uji ChiSquare diperoleh $\mathrm{p}$ value 0,625 yang lebih besar dari 0,05 yang berarti secara statistik adalah tidak signifikan sehingga dapat diketahui bahwa dukungan keluarga responden tidak berhubungan terhadap respons OHIDHA.

Hasil tabulasi silang juga menunjukkan bahwa dari 27 OHIDHA yang mendapatkan dukungan dari keluarga besar kurang mendukung yaitu skor dukungan keluarga kurang dari 11 yang memberikan respon negatif sebesar 48,1\% lebih banyak proporsinya dibandingkan dengan yang mendapatkan dukungan dari keluarga besar mendukung yaitu skor dukungan keluarga lebih dari sama dengan 11 (40,0\%). Semakin banyak responden dengan dukungan keluarga yang mendukung maka 
semakin tinggi responden yang mempunyai respons positif. Begitu juga sebaliknya, semakin banyak responden dengan dukungan keluarga kurang mendukung maka semakin tinggi responden yang mempunyai respons negatif.

Sesuai dengan teori Green yang menyatakan penguat atau reinforcing factor adalah faktor yang memperkuat untuk terjadinya perilaku tertentu. Green menyatakan bahwa faktor-faktor yang menguatkan (reinforcing factor) yang termasuk di dalamnya adalah dukungan orang lain termasuk teman sebaya, majikan, tokoh masyarakat, orang tua dan para guru akan mempengaruhi secara langsung terhadap perilaku seseorang (KEMENKES, 2009). Salah satu yang termasuk di dalam faktor penguat ini adalah keluarga besar.

Keluarga besar adalah salah satu reinforcing factor atau faktor penguat OHIDHA dalam memberikan respons. Berdasarkan hasil FGD dengan ODHA, keluarga besar belum semua memberikan dukungan terkait dengan HIV AIDS. Keluarga besar belum memberikan bantuan pengobatan kepada ODHA.

Hal ini sesuai dengan penelitian yang dilakukan oleh Nugrahawati bahwa bagi ODHA bentuk dukungan dari keluarga yang paling diharapkan adalah perhatian, empati, berbagi perasaan dan merasa dihargai (Nugrahawati, 2011).

\section{Dukungan Teman}

Berdasarkan hasil penelitian menunjukkan bahwa sebagian besar responden mempunyai dukungan teman yang mendukung yaitu sebesar $71,7 \%$. Sedangkan responden yang kurang mendapatkan dukungan dari teman sebesar $28,3 \%$. Secara lebih mendalam, dukungan dari teman yang kurang yaitu sebanyak $55,4 \%$ teman OHIDHA tidak memberikan informasi tentang HIV AIDS kepada OHIDHA. Sebanyak $34,8 \%$ teman OHIDHA tidak memberikan dukungan dalam merawat ODHA. Sebanyak 29,3\% teman tidak menganggap berharga karena mempunyai keluarga ODHA. Sebanyak $27,2 \%$ teman OHIDHA takut untuk main ke rumah OHIDHA.

Berdasarkan hasil analisis uji ChiSquare diperoleh $\mathrm{p}$ value 0,489 yang lebih besar dari 0,05 yang berarti secara statistik adalah tidak signifikan sehingga dapat diketahui bahwa dukungan teman responden tidak berhubungan terhadap respons OHIDHA.

Hasil tabulasi silang juga menunjukkan bahwa dari 26 OHIDHA yang mendapatkan dukungan teman kurang mendukung yaitu skor dukungan teman kurang dari 4 yang memberikan respon negatif sebesar 50\% lebih banyak proporsinya dibandingkan dengan yang mendapat dukungan teman mendukung yaitu skor dukungan teman lebih dari sama dengan $4(39,4 \%)$. 
Sesuai dengan teori Green yang menyatakan penguat atau reinforcing factor adalah faktor yang memperkuat untuk terjadinya perilaku tertentu. Green menyatakan bahwa faktor-faktor yang menguatkan (reinforcing factor) yang termasuk di dalamnya adalah dukungan orang lain termasuk teman sebaya, majikan, tokoh masyarakat, orang tua dan para guru akan mempengaruhi secara langsung terhadap perilaku seseorang. Salah satu yang termasuk di dalam faktor penguat ini adalah teman (Green, 2000).

Teman adalah salah satu reinforcing factor atau faktor penguat OHIDHA dalam memberikan respons. Namun, masih ada teman OHIDHA yang tidak memberikan informasi tentang HIV AIDS kepada OHIDHA, tidak memberikan dukungan dalam merawat ODHA, tidak menganggap berharga karena mempunyai keluarga ODHA dan takut untuk main ke rumah OHIDHA.Berdasarkan hasil FGD dengan ODHA, teman OHIDHA belum semua memberikan dukungan terkait dengan HIV AIDS. Teman OHDHA belum memberikan informasi yang komprehensif kepada OHIDHA. Sehingga lingkungan di sekitar yang tidak kondusif seperti masih adanya stigma.

\section{Dukungan Tokoh Masyarakat}

Berdasarkan hasil penelitian menunjukkan bahwa sebagian besar responden mempunyai dukungan tokoh masyarakat yang mendukung yaitu sebesar $84,8 \%$ sedangkan responden yang mempunyai dukungan tokoh masyarakat yang kurang mendukung sebesar 15,2\%. Secara lebih mendalam, tokoh masyarakat yang kurang mendukung yaitu sebanyak $72,8 \%$ tokoh masyarakat OHIDHA tidak memberikan dukungan perawatan pada penderita HIV AIDS. Sebanyak 66,3 \% tokoh masyarakat OHIDHA tidak memberikan dukungan berupa penerimaan kepada penderita HIV AIDS.

Berdasarkan hasil analisis uji ChiSquare diperoleh $p$ value 0,740 yang lebih besar dari 0,05 yang berarti secara statistik adalah tidak signifikan sehingga dapat diketahui bahwa dukungan tokoh masyarakat responden tidak berhubungan terhadap respons OHIDHA.

Hasil tabulasi silang juga menunjukkan bahwa dari 14 OHIDHA yang mendapatkan dukungan dari tokoh masyarakat kurang mendukung yaitu skor dukungan tokoh masyarakat kurang dari 3 yang memberikan respon negatif sebesar 50\% lebih banyak proporsinya dibandingkan dengan yang mendapatkan dukungan tokoh masyarakat mendukung yaitu skor dukungan tokoh masyarakat lebih dari sama dengan 3 (41\%). Semakin banyak responden dengan dukungan tokoh masyarakat yang mendukung maka semakin tinggi responden yang mempunyai respons positif. Begitu juga dengan semakin banyak responden 
dengan dukungan tokoh masyarakat kurang mendukung maka semakin tinggi responden yang mempunyai respon negatif.

Sesuai dengan teori Green yang menyatakan penguat atau reinforcing factor adalah faktor yang memperkuat untuk terjadinya perilaku tertentu. Green menyatakan bahwa faktor-faktor yang menguatkan (reinforcing factor) yang termasuk di dalamnya adalah dukungan orang lain termasuk teman sebaya, majikan, tokoh masyarakat, orang tua dan para guru akan mempengaruhi secara langsung terhadap perilaku seseorang. Salah satu yang termasuk di dalam faktor penguat ini adalah tokoh masyarakat (Green, 2000). Dalam penelitian ini tokoh masyarakat masih tidak memberikan dukungan perawatan pada penderita HIV AIDS dan tidak memberikan dukungan berupa penerimaan kepada penderita HIV AIDS.

Gambaran Umum Karakteristik OHIDHA

Umur

Setengah responden yaitu sebesar $50 \%$ termasuk dalam kategori muda, sedangkan sisanya sebesar $50 \%$ responden termasuk dalam kategori tua. Muda adalah pengkategorian umur dari umur 17-29 tahun, sedangkan pengkategorian umur tua dari umur 29,5-58 tahun. Rata-rata umur responden dalam penelitian ini adalah 32 tahun, responden dengan usia paling muda adalah berumur 17 tahun dan repsonden dengan usia paling tua adalah berumur 58 tahun.

Analisis statistik bivariat menyatakan bahwa tidak terdapat hubungan yang signifikan $(p$ value $=0,673)$ antara umur responden dengan respons OHIDHA. Penelitian ini sama dengan penelitian Natalia Kristi tentang Analisis Beberapa Faktor yang Mempengaruhi Perilaku Masyarakat Menghadapi Penderita HIV dan AIDS di Desa Kramat Kecamatan Kranggan Kabupaten Temanggung bahwa tidak ada hubungan yang bermakna antara karakteristik responden dengan perilaku masyarakat dalam menghadapi penderita HIV AIDS (Kristi, 2008).

Berdasarkan analisis tabulasi silang penelitian ini menunjukkan bahwa dari 46 OHIDHA yang berumur tua yaitu umur 29,5-58 tahun yang memberikan respon negatif sebesar $45,7 \%$ lebih banyak proporsinya dibandingkan dengan yang berumur muda yaitu umur 17-29 tahun $(39,1 \%)$. Artinya, semakin tua usia responden maka semakin banyak responden yang memberikan respon negatif. Begitu juga sebaliknya, semakin banyak responden yang berusia muda maka semakin tinggi responden yang mempunyai respon positif.

Menurut Green, perilaku ditentukan oleh 3 faktor, salah satunya adalah faktor predisposisi yang di dalamnya terdapat karakteristik seseorang. Salah satu karakteristik dalam penelitian ini adalah 
umur. Kategori umur muda lebih peduli terhadap ODHA dibanding dengan kategori umur tua karena biasanya kategori umur muda ini mereka cenderung lebih aktif untuk menerima maupun mencari informasi. Sehingga, ketika informasi yang mereka dapatkan cukup, maka kepedulian mereka terhadap ODHA juga cukup.

\section{Pendidikan}

Hasil analisis statistik univariat menunjukkan hasil bahwa sebagian besar responden yaitu $77,2 \%$ menyelesaikan pendidikan dasar yaitu SD atau SMP sederajat, kemudian $22,8 \%$ menyelesaikan pendidikan menengah yaitu SMA. Dari hasil analisis statistik bivariat dengan uji Chi- Square diketahui bahwa signifikansinya 0,481 yaitu lebih dari 0,05 yang berarti bahwa tidak ada hubungan pendidikan responden dengan respons OHIDHA.

Berdasarkan hasil tabulasi silang menunjukkan bahwa dari 71 OHIDHA yang berpendidikan rendah yaitu tidak sekolah, SD dan SMP yang memberikan respon negatif sebesar $45,1 \%$ lebih banyak proporsinya dibandingkan dengan yang berpendidikan menengah yaitu SMA sederajat $(33,3 \%)$.Artinya, semakin tinggi pendidikan responden maka semakin tinggi responden yang mempunyai respons positif. Begitu juga dengan semakin banyak responden dengan pendidikan rendah maka semakin tinggi responden yang mempunyai respon negatif.

Pendidikan sebagai faktor predisposisi, yaitu faktor internal seseorang yang berpengaruh terhadap terjadinya perubahan perilaku. Brotosaputro juga mengatakan bahwa tingkat pendidikan individu merupakan faktor yang penting mempengaruhi pengetahuan. Artinya, semakin tinggi pendidikan maka semakin mudah dalam menyerap pengetahuan dan semakin mudah pula untuk melakukan praktik sesuai dengan pengetahuan yang didapatkan.

Hal ini sama dengan penelitian, yang dapat dilihat dari hasil tabulasi silang yang menunjukkan bahwa responden yang menyelesaikan pendidikan sampai jenjang menengah (tamat SMA) cenderung untuk memberikan respons positif daripada responden yang menyelesaikan sampai jenjang pendidikan dasar (SD dan SMP).

Menurut Notoatmodjo, pendidikan merupakan upaya yang direncanakan untuk mempengaruhi orang lain baik individu, kelompok maupun masyarakat. Dimana pendidikan yang lebih tinggi akan lebih banyak menerima informasi sehingga lebih memperhatikan kesehatannya. Hasil penelitian sejalan dengan pendapat Notoatmodjo yang menyatakan bahwa makin tinggi pendidikan seseorang makin mudah seseorang tersebut menerima informasi. Dengan pendidikan tinggi maka 
seseorang cenderung untuk mendapatkan informasi baik dari orang lain maupun dari media. Pada umumnya memang diperoleh bahwa seseorang yang berpendidikan tinggi akan lebih cepat dan mudah dalam menyerap informasi yang diterimanya.

Tingkat pendidikan formal merupakan tolok ukur bagi seseorang untuk lebih mudah dalam memberikan persepsi, respon ataupun tanggapan mengenai segala sesuatu dari luar. Semakin tinggi pendidikan seseorang maka akan semakin rasional pula persepsi atau respon yang diberikan daripada mereka yang berpendidikan rendah. Sesuai dengan hasil tabulasi silang yang menunjukkan bahwa semakin tinggi pendidikan responden maka akan cenderung untuk memberikan respons positif karena lebih mudah menyerap informasi, edukasi mengenai HIV AIDS baik yang diberikan oleh provider dan ODHA.

\section{Pekerjaan}

Hasil analisis statistik univariat menunjukkan hasil bahwa sebagian besar responden yaitu $65,2 \%$ bekerja, kemudian $34,8 \%$ tidak bekerja. Dari hasil analisis statistik bivariat dengan uji Chi-Square diketahui bahwa signifikansinya 0,977 yaitu lebih dari 0,05 yang berarti bahwa tidak ada hubungan pekerjaan responden dengan respons OHIDHA. Berdasarkan hasil tabulasi silang menunjukkan bahwa dari 60 OHIDHA yang bekerja yang memberikan respon negatif sebesar 43,3\% lebih banyak proporsinya dibandingkan dengan yang tidak bekerja $(40,6 \%)$.

Menurut teori bahwa pekerjaan berhubungan dengan status sosial ekonomi seseorang, dimana akan menentukan tersedianya suatu fasilitas yang diperlukan untuk kegiatan tertentu, sehingga status sosial ekonomi ini akan mempengaruhi perilaku seseorang. Dalam penelitian ini, tidak sesuai dengan teori bahwa mereka yang tidak bekerja mempunyai respons yang positif.

Berdasarkan hasil tabulasi silang antara pekerjaan dan sumber informasi yang didapatkan bahwa dari 14 responden yang tidak bekerja yang mendapatkan sumber informasi sedikit sebanyak $35,7 \%$ lebih banyak proporsinya dibandingkan dengan responden yang mempunyai sumber informasi banyak $34,6 \%$.

\section{Agama}

Hasil analisis statistik univariat menunjukkan hasil bahwa semua responden beragama Islam. Mengingat mayoritas penduduk di wilayah penelitian yaitu Kabupaten Sukoharjo dan Kabupaten Grobogan adalah penganut agama Islam. Sehingga tidak menutup kemungkinan bahwa semua responden juga beragama Islam.

\section{Hubungan dengan ODHA}

Berdasarkan hasil penelitian menunjukkan bahwa sebagian besar 
responden merupakan keluarga inti yaitu sebesar 73,9\% sedangkan responden yang mempunyai hubungan keluarga bukan sebagai keluarga inti sebesar 26,1\%. Dari hasil analisis statistik bivariat dengan uji Chi-Square diketahui bahwa signifikansinya 0,025 yaitu kurang dari 0,05 yang berarti bahwa ada hubungan, hubungan dengan ODHA responden dengan respons OHIDHA. Berdasarkan hasil tabulasi silang menunjukkan bahwa dari 68 OHIDHA yang merupakan keluarga inti ODHA yaitu suami, istri, anak, bapak, ibu yang memberikan respon negatif sebesar 52,9\% lebih banyak proporsinya dibandingkan dengan yang merupakan bukan keluarga inti yaitu keponakan, paman, bibi, nenek $(12,5 \%)$.

Keluarga sebagai unit terkecil di masyarakat akan paling merasakan dampak psikososial masalah HIV AIDS, misalnya untuk perawatan penderita. Peranan keluarga, baik keluarga inti maupun keluarga jaringan akan semakin dibutuhkan. Keluarga akan menjadi tempat untuk bernaung, untuk mendapatkan perawatan, untuk mendapat kasih sayang bagi penderita dan anak-anak yang ditinggalkan oleh kedua orang tuanya yang direnggut oleh keganasan AIDS.

Dampak psikososial HIV AIDS juga akan dirasakan sampai di tingkat rumah tangga. Keluarga mau tidak mau akan menanggung beban keuangan yang cukup berat seandainya ada anggota keluarga yang terinfeksi HIV, apalagi yang terinfeksi adalah suami atau anggota keluarga lainnya sebagai pencari nafkah (dampak ekonomi pada AIDS). Keluarga akan terbebani biaya pengobatan yang mahal untuk perawatan penderita. Selain itu, keluarga sebagai komunitas yang terkecil di masyarakat juga akan menerima beban mental yang cukup berat. Misalnya timbul reaksi sosial dalam bentuk pengucilan, perceraian dan berbagai konflik rumah tangga lainnya. Demikian halnya dengan penelitian ini, respons negatif diberikan oleh anggota keluarga inti karena pengukuran respons adalah respons sekarang, sementara semakin lama ODHA hidup, maka beban yang harus ditanggung keluarga inti semakin besar. Misalnya terkait dengan biaya perawatan dan produktivitas.

Selain itu, berdasarkan hasil tabulasi silang antara hubungan dengan ODHA dengan pekerjaan responden menunjukkan bahwa dari 60 OHIDHA yang bekerja yang merupakan keluarga inti sebanyak 78,3\% lebih banyak proporsinya dibandingkan dengan yang tidak bekerja sebesar $65,6 \%$.

\section{Lama hidup dengan ODHA}

Berdasarkan hasil penelitian menunjukkan bahwa sebagian besar responden yaitu sebesar $52,2 \%$ telah hidup bersama ODHA lama, kemudian 47,8\% masih tergolong hidup baru dengan ODHA. Dari hasil analisis statistik bivariat dengan 
uji Chi-Square diketahui bahwa terkait dengan biaya perawatan dan signifikansinya 0,030 yaitu kurang dari 0,05 produktivitas.

yang berarti bahwa ada hubungan lama

Lama mengetahui status ODHA

hidup dengan ODHA responden dengan

Berdasarkan hasil penelitian respons OHIDHA. Berdasarkan hasil menunjukkan bahwa sebagian besar tabulasi silang menunjukkan bahwa dari 48 responden yaitu sebesar $51,1 \%$ telah OHIDHA yang telah lama hidup dengan mengetahui status ODHA lama, kemudian ODHA yaitu selama 24-96 bulan yang $48,9 \%$ masih tergolong baru mengetahui memberikan respon negatif sebesar $54,2 \%$ lebih banyak proporsinya dibandingkan dengan yang baru hidup dengan ODHA yaitu 1-23 bulan $(39,1 \%)$.

Dampak psikososial HIV AIDS juga akan dirasakan sampai di tingkat rumah tangga. Keluarga mau tidak mau akan menanggung beban keuangan yang cukup berat seandainya ada anggota keluarga yang terinfeksi HIV, apalagi yang terinfeksi adalah suami atau anggota keluarga lainnya sebagai pencari nafkah (dampak ekonomi pada AIDS). Keluarga akan terbebani biaya pengobatan yang mahal untuk perawatan penderita. Selain itu, keluarga sebagai komunitas yang terkecil di masyarakat juga akan menerima beban mental yang cukup berat. Misalnya timbul reaksi sosial dalam bentuk pengucilan, perceraian dan berbagai konflik rumah tangga lainnya. Demikian halnya dengan penelitian ini, respons negatif diberikan oleh responden yang telah hidup lama dengan ODHA karena semakin lama ODHA hidup, makan beban yang harus ditanggung semakin besar. Misalnya status ODHA. Dari hasil analisis statistik bivariat dengan uji Chi-Square diketahui bahwa signifikansinya 0,001 yaitu kurang dari 0,05 yang berarti bahwa ada hubungan lama mengetahui status ODHA responden dengan respons OHIDHA. Berdasarkan hasil tabulasi silang menunjukkan bahwa dari 47 OHIDHA yang telah lama mengetahui status HIV ODHA yaitu selama 22-84 bulan yang memberikan respon negatif sebesar $59,6 \%$ lebih banyak proporsinya dibandingkan dengan yang baru mengetahui status ODHA yaitu 1-21 bulan $(24,4 \%)$.

Dampak psikososial HIV AIDS juga akan dirasakan sampai di tingkat rumah tangga. Keluarga mau tidak mau akan menanggung beban keuangan yang cukup berat seandainya ada anggota keluarga yang terinfeksi HIV, apalagi yang terinfeksi adalah suami atau anggota keluarga lainnya sebagai pencari nafkah (dampak ekonomi pada AIDS). Keluarga akan terbebani biaya pengobatan yang mahal untuk perawatan penderita. Selain itu, keluarga sebagai komunitas yang terkecil di masyarakat juga 
akan menerima beban mental yang cukup berat. Misalnya timbul reaksi sosial dalam bentuk pengucilan, perceraian dan berbagai konflik rumah tangga lainnya. Demikian halnya dengan penelitian ini, respons negatif diberikan oleh responden yang telah lama mengetahui status ODHA karena semakin lama ODHA hidup, maka beban yang harus ditanggung semakin besar. Misalnya terkait dengan biaya perawatan dan produktivitas. Mendengar anggota keluarga berstatus ODHA

Berdasarkan hasil penelitian menunjukkan bahwa sebagian besar responden mendengar status ODHA dari ODHA yaitu sebesar 57,6\%. kemudian $42,4 \%$ mendengar status ODHA dari orang lain. Orang lain disini adalah dokter yang bersangkutan dan anggota keluarga lain selain ODHA. Dari hasil analisis statistik bivariat dengan uji Chi-Square diketahui bahwa signifikansinya 0,401 yaitu lebih dari 0,05 yang berarti bahwa tidak ada hubungan mendengar anggota keluarga berstatus ODHA responden dengan respons OHIDHA. Berdasarkan hasil tabulasi silang menunjukkan bahwa dari 39 OHIDHA yang telah mendengar keluarganya ODHA dari orang lain yaitu dokter dan anggota keluarga lainnya yang memberikan respon negatif sebesar $48,7 \%$ lebih banyak proporsinya dibandingkan dengan yang mendengan keluarganya ODHA dari ODHA sendiri $(37,7 \%)$.
Berdasarkan hasil FGD dengan ODHA, bahwa ketika mereka terbuka maka keluarga akan lebih menerima dengan syarat mereka harus menunjukkan bahwa diri mereka sehat dan berperilaku sehat. Namun, sebagian dari ODHA masih kesulitan untuk membuka statusnya. Menurut Greater Involvement of People Living with or Affected by HIV/AIDS (GIPA), kesulitan akan keterbukaan tentang status ODHA terhadap keluarga, komunitas/masyarakat atau pun tempat kerja adalah berbeda-beda pada setiap negara atau budaya. Pada kasus tertentu kewaspadaan diperlukan untuk melindungi orang yang mengungkapkan status HIV positifnya, karena hal ini dapat menciptakan tanggapan yang buruk terhadap diri yang bersangkutan di lingkungan pekerjaannya, keluarga atau komunitasnya. Diskriminasi termanifestasikan dalam berbagai bentuk, dari yang hampir tidak tampak sampai dengan kekerasan fisik. Begitu juga ketakutan ODHA dapat berkisar dari persepsi (yang tidak selalu benar) akan diskriminasi pribadi sampai penolakan dan kekerasan yang bersifat objektif.

\section{SIMPULAN}

Beberapa faktor yang memiliki hubungan secara signifikan secara statistik terhadap respons yaitu hubungan dengan ODHA ( $p$ value $=0,001$ ), lama hidup dengan ODHA 
( $p$-value $=0,030)$, lama mengetahui ODHA ( $p$ value $=0,001)$, sikap $(p$ value $=0,005)$.

Sikap $(p$ value $=0,006)$, lama mengetahui status ODHA ( $p$ value $=0,006$ ) dan hubungan kekeluargaan dengan ODHA ( $p$ value $=0,007$ ) merupakan variabel yang paling berpengaruh terhadap respons OHIDHA. OHIDHA yang memiliki sikap positif memiliki kecenderungan 4,118 kali lebih besar untuk mempunyai respons positif dibandingkan dengan OHIDHA yang mempunyai sikap negatif. OHIDHA

\section{DAFTAR PUSTAKA}

Asia Pasific Regional Analysis. People Living With HIV Stigma Index : UNAIDS. 2011.

Azwar, S. Sikap Manusia: Teori dan Pengukurannya. Penerbit Liberty. Yogyakarta, 2007.

Green LW, Kreuter MW. Health Promoting Palnning : An Educational and environmental Approach. Mayfield Publishing Co. California 2000

Hermawati, Pian. Hubungan Persepsi ODHA Terhadap Stigma HIV/AIDS Masyarakat Dengan Interaksi Sosial. (Skripsi). 2012.

Kementerian Kesehatan Republik Indonesia. Mitos dan Fakta. Jakarta : Kemenkes. 2009.

Kementerian Kesehatan Republik Indonesia. Riset Kesehatan Dasar. 2010. Jakarta : Kemenkes. 2010.

Komisi Penanggulangan AIDS Provinsi Jawa Tengah. Laporan Visitasi KPA Provinsi Jawa Tengah di Kabupaten Grobogan. Semarang : KPAP. 2013.

Kristi, N. Analisis Beberapa Faktor Yang Mempengaruhi Perilaku Masyarakat Menghadapi Penderita yang telah lama mengetahui status OHIDHA memiliki kecenderungan 0,246 kali lebih besar untuk mempunyai respon negatif dibandingkan dengan OHIDHA yang baru mengetahui status HIV ODHA. OHIDHA yang mempunyai hubungan kekeluargaan sebagai keluarga inti memiliki kecenderungan 0,246 kali lebih besar untuk mempunyai respon negatif dibandingkan dengan OHIDHA yang mempunyai hubungan kekeluargaan sebagai keluarga bukan inti.

HIV dan AIDS di Desa Kramat Kecamatan Kranggan Kabupaten Temanggung. (Tesis). 2008.

Narodin. HIV AIDS Pendekatan Biologi Molekuler, Klinik dan Sosial. Surabaya, 2007

Nasronudin. Penanggulangan HIV AIDS di Indonesia Berbasis Biopsikososio-Spiritual Excellence. Pidato Pengukuhan Guru Besar. Universitas Airlangga. Surabaya. 2010.

Notoatmodjo, S. Metodologi Penelitian Kesehatan. Rineka Cipta. Jakarta, 2010.

Notoatmodjo, S. Pendidikan dan Perilaku Kesehatan. Rineka Cipta. Jakarta, 2003.

Nugrahawati, Eni. Hubungan Antara Dukungan Keluarga dengan "Self Esteem" pada ODHA di Yayasan Akses Indonesia Tasikmalaya. Jurnal Fakultas Psikologi Universitas Islam Bandung. 2011; ISSN 2089-3590.

Pusat Studi Kependudukan Universitas Cenderawasih dan University of Victoria. Stigma dan HIV / AIDS 
di Wilayah Pegunungan Papua. 2010 .

Sulistyawan. Ini Testimoni ODHA Butuh Waktu Tiga Tahun Berani Buka Statusnya. Tribun Jawa Tengah 2 Desember 2013. Available for
URL:

http://jateng.tribunnews.com/2013/ 12/02/ini-testimoni-odha-butuhwaktu-tiga-tahun-berani-bukastatusnya 